
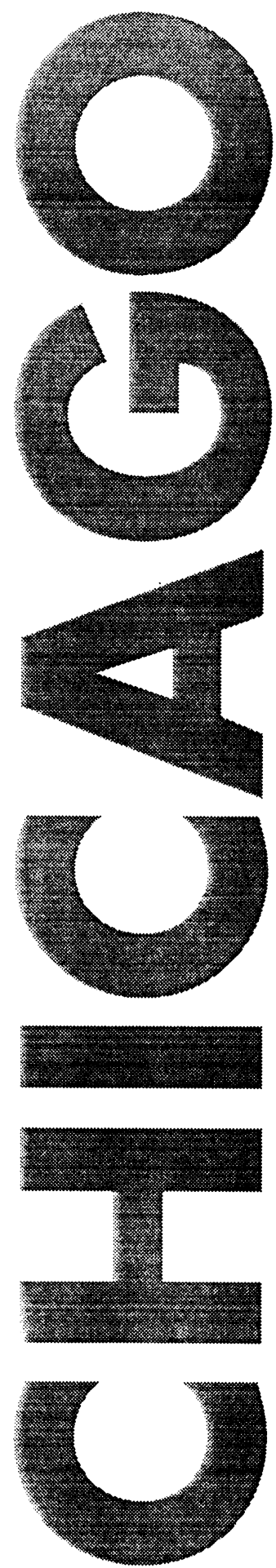

\section{REPRODUCING RAPE}

Domination through Talk in the Courtroom

\section{Gregory M. Matoesian}

Using tape recordings of actual trials, Matoesian looks at the social construction of rape trials and at how a woman's experience of violation can be transformed in the courtroom into an act of routine, consensual sex.

- Paper \$15.95 274 pages

Language and Legal Discourse series

\section{VIOLENCE AND MENTAL DISORDER}

Developments in Risk Assessment

\section{Edited by John Monahan} \section{and Henry J. Steadman}

This comprehensive review of research over the past two decades offers new empirical and theoretical work on mental disorder that will pave the way for more accurate predictions of violent behavior.

Cloth $\$ 34.95344$ pages illus.

The Fobn D. and Catherine T. MacArtbur Foundation Series on Mental Health and Development

\section{POOR DISCIPLINE}

Parole and the Social Control of the Underclass, 1890-1990

\section{Jonathan Simon}

This powerful book reveals how modern strategies of punishment-and, by all accounts, their failure-relate to political and economic transformations in society at large. Simon uses the practice of parole in California as a window to the changing historical understanding of what a corrections system does and how it works.

-Paper $\$ 15.95328$ pagos

\section{THE LANGUAGE OF JUDGES}

\section{Lawrence M. Solan}

In the first book to examine the linguistic analysis of law, Solan shows that judges sometimes inaccurately portray the way we use language, creating inconsistencies in their decisions and threatening the fairness of the judicial system.

- Paper \$16.95 230 pages

Language and Legal Discourse series

* Clotb edition available 


\section{THE SCALE OF IMPRISONMENT}

\section{Franklin E. Zimring Gordon J. Hawkins}

"Its careful review, analysis, and critique of research is stimulating and inventive."

-American Political Science Review

Paper \$12.95 258 pages ilus.

Studies in Crime and fustice

\section{TOURNAMENT OF LAWYERS}

The Transformation of the Big Law Firm

\section{Marc Galanter} and Thomas Palay

"Essential to the understanding of the business of big law firms."-Jean and Colin Fergus, New York Law Journal Paper \$12.95 210 pages illus.

\section{CARDOZO}

\section{A Study in Reputation}

\section{Richard A. Posner}

"The present compact and unflaggingly interesting volume. . . is a full-bodied scholarly biography. ... It is illuminating in itself, and will serve as a significant contribution."

-Paul A. Freund, New York Times Book Review Paper $\$ 10.95168$ pages illus.

\section{MODERN POLICING}

Crime and Fustice, Volume 15

\section{Edited by Michael Tonry} and Norval Morris

Eleven essays reveal the social, political, legal, and technological factors that shape the character of contemporary police agencies.

Paper \$25.00 616 pages

\section{THE HOLLOW HOPE}

Can Courts Bring About Social Change?

\section{Gerald N. Rosenberg}

"[Rosenberg] argues with considerable subtlety and power, and no little persuasiveness, that the promise of the Supreme Court action has been chimerical."-David L. Kirp, The Nation Paper \$16.95 437 pages illus.

American Politics and Political Economy series

\section{PUNISHMENT AND MODERN SOCIETY}

A Study in Social Theory

\section{David Garland}

"This book is a first-class piece of scholarship. It is to be hoped that sociology and criminal justice departments will ... expand their courses on social deviance to include Garland's work."-Graeme Newman, Contemporary

Sociology

Paper \$16.95 318 pages

Studies in Crime and Fustice

- Outstanding Scholarship Award of the Crime and Delinquency Division of the Society for the Study of Social Problems

- Distinguished Scholar Award from the American Sociological Association's Crime, Law and Deviance Section

\section{SCREWING THE SYSTEM AND MAKING IT WORK}

Fuvenile Fustice in the No-Fault Society Mark D. Jacobs

"An excellent ethnographic study. ... [W]ill probably be referenced as a leading example of this methodology."-Susette M. Talarico, Law and Politics Review

Paper \$14.95 304 pages illus. 


\section{Paper Edition Now Available}

\section{MODERN POLICING}

\section{Edited by Michael Tonry and Norval Morris}

These ten essays examine the diverse factors that have shaped the modern police force, focusing on how law enforcement functions and how it has developed into its current state. Historical, technological, and political overviews by leading scholars connect theory, policy, and research from a variety of fields. Much of this valuable information explores new insights which are critical for a more informed understanding of policing issues that face a changing and complex society.

Modern Policing will be a welcome review of current research for scholars of public policy, sociology, psychology, criminology, and legal studies.

Modern Policing in Perspective, Norval Morris and Michael Tonry Police Organization in the Twentieth Century, Albert J. Reiss, Jr.

The Relationship between Public and Private Policing, Clifford Shearing Policing and Crime Control, Lawrence Sherman

Information Technologies and the Police, Peter Manning

Relations between Federal and Local Police, William Geller and Norval Morris

History of Urban Police, Eric Monkkonen

Urban Police and Crime in Nineteenth-Century America, Roger Lane

Police Research in the United Kingdom: A Critical Review, Robert Reiner Organization of Police in English-speaking Countries, David Bayley
1992 Cloth
$\$ 39.95$ $\$ 25.00$
ISBN: 0-226-80813-0
ISBN: 0-226-80814-9
612 pp. Paper

Modern Policing is Volume 15 of the Crime and Justice series.

Order through your bookstore or directly from

The University of Chicago Press

11030 South Langley Avenue

Chicago, Illinois 60628

Or Call: 1-800-621-2736 In Illinois call: 312-568-1550 
The University of Chicago Press cordially invites you to enter your personal subscription to

\section{LAW \& SOCIAL INQUIRY}

New subscribers are eligible for
a $15 \%$ discount off the regular subscription rate. Please return the reply card printed on reverse.

\section{The University of Chicago Press cordially invites you to enter} your personal subscription to

LAW \& SOCIAL INQUIRY

New subscribers are eligible for

a $15 \%$ discount off the regular subscription rate.

Please return the reply card printed on reverse. 


\section{Law \& Social Inquiry}

\section{ENTER A NEW SUBSCRIPTION AND SAVE 25\%!}

$\square$ Individuals

Academic* $^{*}$

Institutions

*For college/university faculty and students.

OUTSIDE USA? Please add $\$ 6.00$ for postage. CANADIANS, please add $7 \%$ GST plus $\$ 6.00$ for postage.

\section{BACK ISSUES AT 50\% OFF:}

Set of 20 available issues:

New

$\$ 27.00(\mathrm{~F})$

$21.75(F)$

44.25 (F)

Renewal

$\square \$ 36.00$

29.00

59.00

\section{$\square$ Charge my $\square$ Visa $\square$ MasterCard Exp. date}

Acct. \#

Signature

Phone (

Check enclosed (payable to Law \& Social Inquiry)

Name

Address

City

State / Country

ZIP

For special savings on two and three year rates, please direct inquiries to The University of

Chicago Press, at the address listed below.

Please mail to The University of Chicago Press, Journals Division,

P.O. Box 37005, Chicago, IL 60637.

\section{Law \& Social Inquiry}

\section{ENTER A NEW SUBSCRIPTION AND SAVE 25\%!}

\begin{tabular}{|c|c|c|}
\hline & New & Renewal \\
\hline Individuals & $\square \$ 27.00(\mathrm{~F})$ & $\square \$ 36.00$ \\
\hline Academic* & $21.75(\mathrm{~F})$ & 29.00 \\
\hline Institutions & $\square \quad 44.25(\mathrm{~F})$ & 59.00 \\
\hline
\end{tabular}

${ }^{*}$ For college/university faculty and students.

OUTSIDE USA? Please add $\$ 6.00$ for postage. CANADIANS, please add $7 \%$ GST plus $\$ 6.00$ for postage.

BACK ISSUES AT $50 \%$ OFF:

Set of 20 available issues:

Individuals \$100.00 $\square$ Institutions \$157.50
Charge my
Visa
MasterCard Exp. date

Acct. \#

Signature

Phone ( )

Check enclosed (payable to Law \& Social Inquiry)

Name

Address

City

State / Country

ZIP

For special savings on two and three year rates, please direct inquiries to The University of Chicago Press, at the address listed below.

Please mail to The University of Chicago Press, Journals Division, P.O. Box 37005, Chicago, le 60637 . 


\section{American Bar Foundation}

\section{BOARD OF DIRECTORS}

President, Robert W. Bennett, Northwestern University School of Law • Vice-President, John C. Deacon, of the Arkansas Bar - Secretary, Robert MacCrate, of the New York Bar - Treasurer, Kenneth J. Burns, Jr., of the Illinois Bar

Jacqueline Allee, St. Thomas University School of Law • Brooksley Born, of the D.C. Bar • Hon. Jerome Farris, United States Court of Appeals, Ninth Circuit • Herschel H. Friday, Jr., of the Arkansas Bar - Daniel Gourash, of the Ohio Bar • Martha L. Minow, Harvard University Law School Robert A. Stein, University of Minnesota Law School • Cathy S. Wright, of the Alabama Bar

ex officio:

R. William Ide, III, President, American Bar Association • George E. Bushnell, Jr., President-Elect, American Bar Association - Philip S. Anderson, Chairman, House of Delegates, American Bar Association - M. Peter Moser, Treasurer, American Bar Association • Bert H. Early, President, American Bar Endowment - Richard L. Thies, Chair, The Fellows of the American Bar Foundation • James W. Hewitt, Vice-Chair, The Fellows of the American Bar Foundation • Marna S. Tucker, Secretary, The Fellows of the American Bar Foundation

\section{OFFICERS}

Bryant G. Garth, Director Joanne Martin, Assistant Director
Anne Tatalovich, Assistant Director

Hayden C. Flor, Jr., Financial Officer

\section{RESEARCH FELLOWS}

Lori B. Andrews, J.D. Yale University

Jonathan D. Casper, Ph.D. Yale University

John L. Comaroff, Ph.D. University of London

Stephen Daniels, Ph.D. University of Wisconsin

Shari S. Diamond, Ph.D. Northwestern University;

J.D. University of Chicago

John J. Donohue, J.D. Harvard University;

Ph.D. Yale University

William L. F. Felstiner, J.D. Yale University

Bryant G. Garth, J.D. Stanford University; Ph.D.

European University Institute

Janet A. Gilboy, Ph.D. Northwestern University

Terence C. Halliday, Ph.D. University of Chicago

James J. Heckman, Ph.D. Princeton

Carol A. Heimer, Ph.D. University of Chicago
John P. Heinz, LL.B. Yale University

Wayne A. Kerstetter, J.D. University of Chicago Karyl A. Kinsey, Ph.D. University of Chicago

E. Allan Lind, Ph.D. University of North Carolina at Chapel Hill

Arthur F. McEvoy, J.D. Stanford University; Ph.D. University of California, San Diego

Elizabeth Mertz, J.D. Northwestern University; Ph.D. Duke University

Robert L. Nelson, J.D., Ph.D. Northwestern University

Susan P. Shapiro, Ph.D. Yale University

Peter Siegelman, Ph.D. Yale University

Kent W. Smith, Ph.D. Harvard University

Christopher L. Tomlins, Ph.D. Johns Hopkins

\section{LIAISON RESEARCH SERVICES PROGRAM}

Joanne Martin, M.M. Northwestern University, J.D. Loyola University

Barbara A. Curran, LL.B. University of Connecticut, LL.M. Yale University 


\section{Law \& Social Inquiry \\ Volume 18, Number 3, Summer 1993}

\section{ARTICLES}

Professional Innovation: Corporate Lawyers and Private Lawmaking MICHAEL J: POWELL

Mrs. John Marshall Harlan's Memories: Hierarchies of Gender and Race in the Household and the Polity

LINDA C. A. PRZYBYSZEWSKI

\section{REVIEW ESSAYS}

Reintegrating Braithwaite: Shame and Consensus in Criminological Theory

CHRISTOPHER UGGEN

Review Commentary

Pride in Criminological Dissensus

JOHN BRAITHWAITE

Review Rejoinder

Beyond Calvin and Hobbes: Rationality and Exchange in a Theory of Moralizing Shaming CHRISTOPHER UGGEN

The Disciplinary Function of Rape's Representation: Lessons from the Kennedy Smith and Tyson Trials JODY FREEMAN

Making Sense of Madison: Nedelsky on Private Property WILLIAM W. FISHER III

Russian Advocates: Before, during, and after Perestroika MICHAEL BURRAGE 